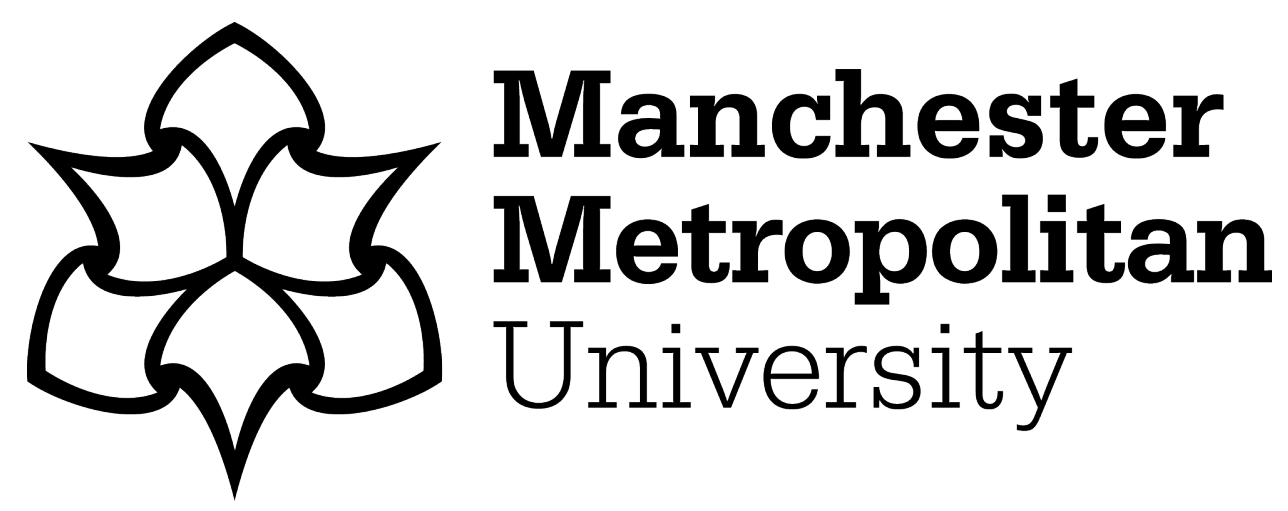

Beel, David, Jones, M and Jones, IR (2018) Regionalisation and Civil Society in a Time of Austerity: The Cases of Manchester and Sheffield. In: Developing England's North: The Political Economy of the Northern Powerhouse. Palgrave Macmillan, pp. 241-260. ISBN 978-3-319-62560-7

Downloaded from: https://e-space.mmu.ac.uk/622029/

Version: Accepted Version

Publisher: Palgrave Macmillan

Please cite the published version 


\title{
Regionalisation and civil society in a time of austerity: the cases of Manchester and Sheffield
}

David Beel, Martin Jones (University of Sheffield) and Ian Rees Jones (Cardiff University)

\begin{abstract}
Within the UK and as well as further afield, the spatial delineation of the 'city region' has seen a renaissance as the de-facto spatial political unit of governance for economic development (Clarke \& Cochrane, 2013). This spatial realignment has been central to the construction of state projects such as the Northern Powerhouse, charged with taking forward the combined agendas of devolution, localism and austerity. The chapter deploys case study research from two city regions (Manchester and Sheffield) to look at the ways in which the city region is being constructed and the different ways in which 'civil society' is negotiating its way through this changing governance landscape. It is in this context that the chapter considers how city regions are being built and the ways in which this process is being limited or undermined through austerity.
\end{abstract}

\section{Introduction}

Since 2010, the UK Government has sought to reshape the ways in which economic development takes place and although this shift in governmental delivery began under New Labour, there has been a continuing emphasis on developing the city region scale to unlock economic growth. It was much vaunted by the Coalition Government elected in 2010 (Deas, 2013), whereby they replaced the Regional Development Agencies (RDAs) with Local Enterprise Partnerships (LEPs) and latterly the morphing of LEPs into Combined Authorities (CAs). These policies were then subsequently continued by the following Conservative administrations (Conservative Party, 2015) through a variety of locality-specific devolution deals. However, despite the rhetoric of the Northern Powerhouse as a flagship policy for delivering economic growth for the North of England (Lee, 2016), it has sat alongside a severe austerity programme that has seen Local Authority (LA) budgets cut significantly. This, therefore, raises difficult questions with regards to the ability of CAs and LAs to address the current and future needs of their populations (Etherington \& Jones, 2016b). Finally, although the context of 'Brexit' and the changing leaders of the Conservative Party means the future of the Northern Powerhouse remains uncertain, the political territorialisation and regionalisation (Harrison, 2014) of the city region has problematised the positon of civil society actors working in their respective city regions.

Concurrently to this and historically within geography as well as more broadly the social sciences, there have been a series of parallel debates simmering away for the past decade (see Jonas \& Ward, 2007 for one such example). These debates have revolved around a well-developed series of discussions that consider the ways in which such spatial-fixes either foster economic development through agglomeration (Harding, 2007) or continue to exacerbate uneven development and spatial disparities (Etherington \& Jones, 2009). The chapter seeks to connect these themes with the realpolitik concerns of delivering devolution, to do this, we follow the development of cityregionalism through these different discourses and unfolding city-deals to allow us to ask: within a language of localism, devolution and austerity, how have civil society actors in Sheffield and Greater Manchester City Regions (SCR and GMCR) sought to deal with city regional development approaches 
and the new governance structures that have been created? These are two key City Regions in the North; thus, focussing on their cases is central to comprehending what kind of Northern Powerhouse growth is being built, and whose interests are being represented, if this to be more than an empty policy husk (Lee, 2016). In turn, the chapter is interested in mapping out the missing elements from the Northern Powerhouse recipe book for economic growth and social democracy. By looking at Manchester and Sheffield, if the Northern Powerhouse is a coordinating frame for city regions in the north of England in terms of their interaction with each other, we are interested in understanding how these bodies are being shaped by devolution.

The chapter accordingly gives an empirical contribution ${ }^{1}$ that sheds light upon the ongoing processes of LA restructuring in Greater Manchester and Sheffield towards combined authority (city region) approaches. Therefore, it will highlight how 'policies are not, after all, merely being transferred over space; their form and their effects are transformed by these journeys' (Peck \& Theodore, 2015: 29). This will be done by engaging with the views of civil society actors on-the-ground, in terms of how they have responded to a shifting governance framework at the local state/city region scale. The chapter will, therefore, address the positioning of civil society within these processes by firstly, giving greater context to the development of city regions as a process of regionalisation. By regionalisation, we mean the process by which 'new regions' are created territorially through changes in governance structures, i.e. the territorial (re-)creation of GMCR and SCR. In following this, it will also consider how austerity has impacted upon these processes. It will then secondly, highlight how this repositions civil society due to the economic rationale of city regions, the changes in governance scale and the creation of new 'citizenship regimes' (Jenson \& Saint-Martin, 2010; also Rutherford, 2006). By focussing upon the positioning of civil society actors, the chapter will highlight how city regionalism and the Northern Powerhouse, more broadly, raises serious queries towards developing notions of an 'inclusive growth' approach (RSA, 2016b; RSA, 2016a). The question becomes whether failure to deliver inclusive growth at the city region scale will reflect a failure to deliver equitable growth within the Northern Powerhouse.

\section{Building the City Regions of the Northern Powerhouse}

The UK government has sought to reshape the map of governance in England. One part of the solution to this has been the creation of the Northern Powerhouse. The Northern Powerhouse can be seen as a policy framing device, in which a series of ongoing projects have been placed (Lee, 2016). The powerhouse represents what Jessop (2015: 38) would call a 'spatial imaginary' -a discursive phenomena that distinguishes, by carving out distinctiveness, specific places and spaces "from the inherently unstructured complexity of a spatialized world" - and is well represented rhetorically in Figure 1, whereby economic success and growth is emphasised by the role Northern Powerhouse cities have in providing employment in their metropolitan centres.

\footnotetext{
${ }^{1}$ All empirical material is based upon 30 semi-structured interviews with key civil society stakeholders in both GMCR and SCR, supported by funding from the ESRC, Grant ES/L0090991/1 WISERD Civil Society.
} 


\section{Northern Powerhouse factsheet}

The geography of jobs across the Northern Powerhouse

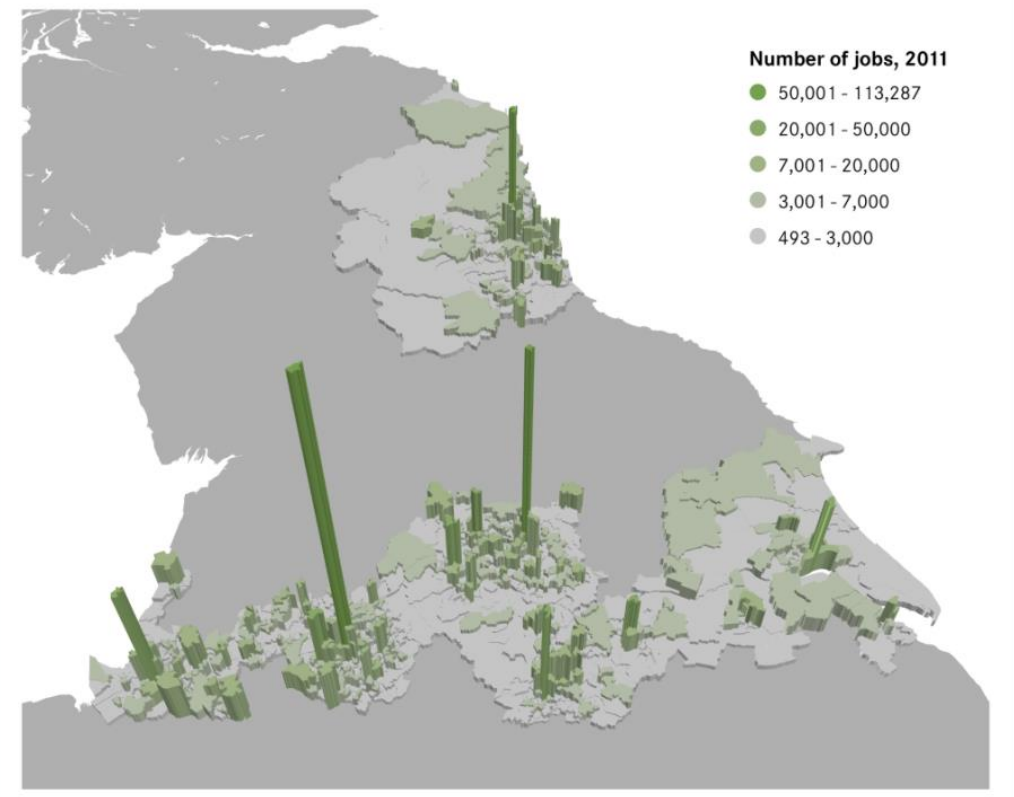

Source: NOMIS, 2015. Census 2011, occupation. MSOA level.

\section{Read the factsheet:}

centreforcities.org/northern-powerhouse-factsheet

\section{centreforcities}

Figure 1 - Centre for Cities Northern Powerhouse Factsheet

The Northern Powerhouse agenda, has therefore framed the more substantial restructuring of (some) local authorities into combined authority city regions. This has been based upon a city first approach whereby, to date city region devolution has focussed around the existing metropolitan footprints of the core UK cities (Jones et al., 2015; Harrison \& Heley, 2014). The momentum for this has been developed due to a number of factors which the UK State has attempted to deal with. Firstly, it was very much a post-crisis reaction in order to stimulate economic growth with the city region vaunted as the de facto scale for growth (Overman, 2012). This reflected both a dominant policy discourse in urban development (see Storper, 2013 for such an example) and a perceived failure of RDAs (Pugalis \& Townsend, 2012). Secondly, it has sought to address the longstanding issue of balance within the UK economy whereby an overheating south is contrasted by an underperforming north (Clarke et al. 2016; Martin et al. 2016; Gardiner et al. 2013). Thirdly, the UK State (with specific reference to England) is renowned for being the most centralised in Western Europe hence with the failure of regional devolution (beyond Wales, Scotland and London) under New Labour (Goodwin et al. 2005), devolution to a suitable scale within England has been sought (Pike et al. 2012). Fourthly, via the deal-making approach, it has attempted to embed austerity into the reformulation of combined authorities through a process of block grant reduction and rationalisation. 
The city region scale has become the dominant discourse in urban development policy (see Storper, 2014) and this has developed due to a number of reasons and analytical frames such as the rise of 'New Regionalism' (Brenner et al. 2003; Keating et al. 2003) and the influence of New Economic Geography (NEG) in placing specific emphasis upon the growing of regions for economic purposes (MacLeod, 2001). Within both these accounts of economic and regional geography, there is an implicit understanding given that the city region is both the 'natural' and 'functional' scale for economic development. It is suggested, that where nation states have failed to deal with macroeconomic shifts in the global economy, city regions represent the suitable scale whereby they are small enough but big enough to deal with this challenge (Scott, 2001).

Central to this has been a belief in Agglomeration Theory (Overman et al. 2007; Overman, 2013; cf. Haughton et al. 2014) as the driver to economic development, whereby city regions open themselves up to attract in as much investment as they can, so that trickles-down in turn to their populations. The city region, therefore, represents a governance strategy that seeks to harness agglomeration and share this geographically. According to an important account of this logic:

The policy implications of theories of agglomeration is that enabling people and firms to benefit from proximity to centres of activity, bring beneficial economic outcomes ... This implies empowering and incentivising local government, firms and people across economic centres and natural economic geographies [Cities] to promote growth and correct the market and government failures which are acting as barriers to economic development (BIS. 2010: 25).

The BIS quote neatly highlights this underpinning to government rhetoric and role it sees local government and business having in to order to address the past failures of both the market and government. Key to this, from their thinking, is to create an agglomerative economy in each of the city regions; quite simply, everyone can win. As Figure 1 suggests, this then links up, or agglomerates, to form the Northern Powerhouse, which is presented as the 'spatial imaginary' to eventually match London in economic terms (HM Government \& Transport for the North, 2015).

In placing a primarily economic focus upon the Northern Powerhouse agenda, which is emphasized by the development of soft-institutional organisations (Haughton et al. 2013) such as Local Enterprise Partnerships (LEPs), this importantly rescales the 'representational regime' of the city region (Jessop, 2015; Macleod \& Goodwin, 1999; Cox, 1997), in a spatially-specific and strategic ways, linked in turn to creating new 'citizenship regimes' for the governance of city regions. This notion captures:

Who qualifies and is recognized as a model citizen is under challenge. The legitimacy of group action and the desire for social justice are losing ground to the notion that citizens and interests can compete equally in the political marketplace of ideas (Jenson and Phillips, 1996:112).

In the context of Greater Manchester and Sheffield City Regions (see figure 2 for broad outline), the new business orientated representational regime, by design, places civil society on the outside. This means that what would could broadly be termed as the 'social reproduction of the city', is given secondary status to its economic drivers (Jonas \& Ward, 2007). This, in turn, positions civil society actors as no longer directly and centrally relevant within the context of chasing agglomerative growth. 
Many have been critical to this approach for a number of reasons (See Beel et al. forthcoming for a more in-depth account of this) but there are three important areas of critique to consider here, within the context of a Northern Powerhouse: one, for continuing uneven regional and city regional development (Etherington and Jones, 2009, 2015), in terms of the failure for agglomerative approaches to trickle down to those that need it most; two, how this pitches city regions against each other in a competitive race to capture investment (Harrison, 2007), questioning the potential of the Northern Powerhouse as represented in Figure 1; and three, who such strategies empower and disempower within the city region (see Rutherford, 2006). The final point is central to the continuing aim of this chapter, in terms of thinking what such an economically-driven strategy means for those who sit outside of this rubric for growth. The 'representational regime' (Jessop, 2015) of the city region is central to this and to date, city region devolution has only sought to strategically engage business communities in terms of dealing with government and market failure. This raises difficult questions for those that operate within what could be broadly termed 'civil society', who are often working with those who benefit least from agglomerative strategies. This reflects a failure to properly integrate a social or inclusive dimension into devolution, due to its narrow focus on economic development. Despite many devolution deals having been put in place, this is only now starting to be discussed as a concern, in the continuing process of implementing devolution. An example of this can be seen in the RSA's Inclusive Growth Commission, which is seeking to identify practical ways to make local economies across the UK more economically inclusive and prosperous (RSA, 2016a). The chapter next frames devolution in Sheffield and Manchester, before addressing the position of civil society more directly within this rescaling of governance.

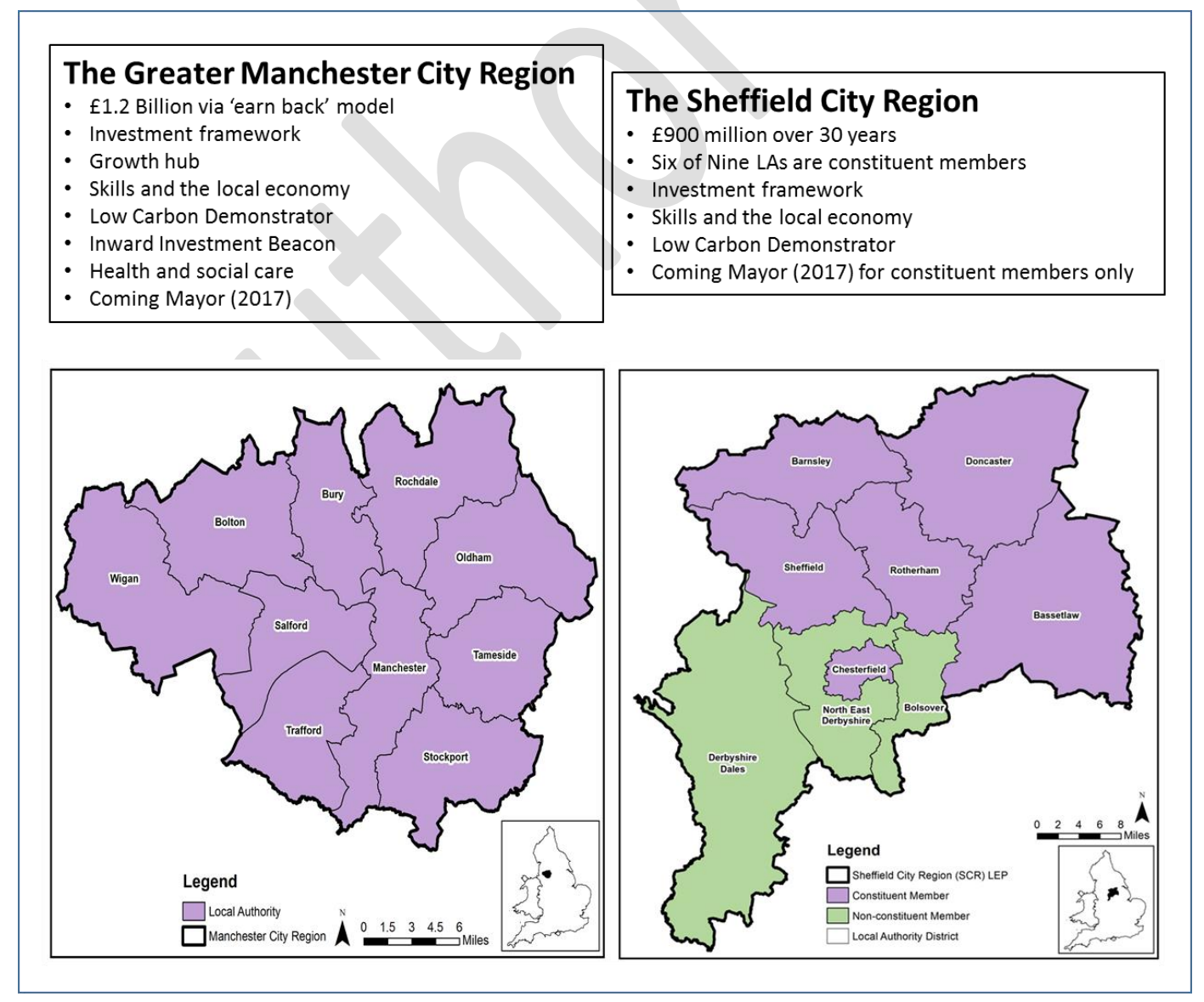

Figure 2 - Outline of GMCR and SCR devolution deals alongside LA membership. 


\section{Placing Civil Society in the City Region}

The chapter's empirical material is based upon thirty semi-structured interviews with civil society actors. Civil society is used as a catch all term for a number of different types of organisation, which are separate from both the state and business. This includes organisations such as charities, those termed third sector, voluntary groups, community groups (of both place and identity), social enterprises, and housing associations. They all have very different relationships with both the local state and business in terms of how they operate. Some have contractual relationships, whereby they deliver specific services, others act to give specific representation to minority groups, and different groups work on very different spatial scales. From across a city region to very localised, neighbourhood development. What ties them together as a set of groups is their individual organisational remit to produce or engender some form of social benefit for their perceived communities. The interviews where not discussing the development of the Northern Powerhouse specifically, but more broadly the development of the city region building agenda. However, as has been previously stated, the development of city regions is central to development of the Northern Powerhouse as a 'spatial imaginary' and GMCR and SCR are two key cases in point in this respect. Hence the following responses should be viewed in the context of what do such approaches to city regions mean for discourses surrounding the Northern Powerhouse.

In framing current developments in devolution from a UK state perspective and from within both SCR and GMCR, it is important to consider the ways in which civil society actors are dealing with this changing governance structure. Jones et al. (2015) highlight how in Liverpool and Bristol, the changing governance landscape and the reduction in funding opportunities through austerity has made things more difficult for groups that sit within what is broadly terms civil society ${ }^{2}$. This has been reflected in both GMCR and SCR, as austerity has impacted those hardest, in the most deprived areas of each city region (Beatty \& Fothergill, 2016), often where such groups are more active and needed. However, civil society members have also highlighted a number of opportunities to mitigate this (despite being problematic) within the context of devolution and in spite of the difficulties of austerity. Below we analyse how civil society actors have struggled with devolution, but also have attempted to find new positions and strategies on which to see their social agendas addressed against the economic framework.

\section{Struggling with the Economic Rationale}

For many groups, there have been a number of problems that devolution and the rhetoric of the Northern Powerhouse have failed to address. These issues initially focuses upon the economic emphasis of city regions, which places civil society on the outside but also misses the need to help those who are most disadvantaged within CRs. According to one source:

I think of Greater Manchester as having a ring donut economy, it's a lot like a North American city. So you have thriving city centre, which it didn't have twenty-five years ago. The suburbs actually doing ok and then the middle bit. If they do not do something about that is really meaningful in that ring donut, the powers that be will never achieve their economic goals of achieving a fiscal balance for this conurbation (Interview 7, Salford Social Enterprise, 2016).

\footnotetext{
${ }^{2}$ Groups from the voluntary, community and social enterprise sectors.
} 
The above highlights how from the outset there is a perception that the growth model proposed for GMCR fails to address the broader problems faced by the city region. This is caused by the ongoing geo-history of inequality but also how this is compounded by pursuit of an agglomerative growth strategy. This is also reflected in views held in Sheffield:

Trickledown doesn't work for the most vulnerable and disadvantaged and you have to have strategies around social regeneration (for want of a better word) alongside economic regeneration. Those two things should come together and I don't think they do because the LEP is very purely focused on the economic policy... Feels like I'm in a rowing boat and my colleagues are in a rowing boat and we're trying to turn round this big tanker (Interview 1, Sheffield Community Development Group, 2015).

For both respondents, one a social enterprise, primarily focussed upon projects in Salford, and the other a community development organisation in a deprived area of Sheffield, the urban growth machine strategy (Logan \& Molotch, 1987; Jonas \& Wilson, 1999) is deeply problematic. As they pick out how the 'trickledown' approach that implies a strategy of developing high level GVA uplift by bringing people to jobs within the city region (Etherington \& Jones, 2016a), does little for the disadvantaged citizens they are attempting to support. This means that because they question the rhetoric of this growth model, they are left on the periphery of its strategic delivery. This is also reflected in the above quote, which highlights how such groups, operating at a local level, have little ability or remit in the context of devolution to act at the city region level and there is an ongoing lack of accountability that marginalises local civil society through institutions such as the LEP. According to one source:

What opportunity will there be to genuinely involve civil society in the process? Because I think the LEP has been and I know it is an economic driver, fine and it's about inward investment, economic growth and the private sector is at the heart of that but there is very little in terms of any wider involvement. And maybe that's ok but when it comes to the combined authority, there needs to be more direct lines of accountability into localities and into local areas (Interview 3, Sheffield Community Development Group, 2015).

Therefore, the construction of a new 'representational regime' for the city region based upon economic interests purposefully excludes civil society actors from the outset, which in turn allows for an uncontested agglomerative growth model to be developed. The following section addresses this by thinking further through how civil society is being positioned and marginalised differently at different scales.

\section{Dealing with Scale?}

The difficulty to have a voice within such processes, due to the failure for civil society groups to be integrated into the representational regime of the city region, has left some squeezed between the 'scale jump' of the City Region (Cox, 1997) and austerity occurring at the same time. According to one interviewee:

At one point they talk about localism but if you look at regionalisation, it's huge, it's huge and actually the local voluntary community sector can't even hope to engage with, let alone deliver against that agenda. Therefore civil society is finding itself squeezed behind/between a rhetoric that emphasises its importance but a reality which mitigates against its ability to 
capture the resources to deliver against that agenda (Interview 12, Bolsover Voluntary

Organisation, 2016).

This quote highlights the difficulties for civil society organisations to deal with austerity and devolution at the same time. It also shows the way in which civil society groups are co-opted and recast into a neoliberal growth model. In short, civil society groups are both needed for the continuing function of the city region, but at the same time they are marginalised within rescaling processes too. There is also appreciation of how LAs are struggling to deal with this rescaling process too within the context of austerity:

To be honest, they are holding what they can, both in Tameside and Oldham, they are holding everything that they can. We are predominantly funded through the local authorities, Tameside get us a fair bit from their CCG [Clinical Commissioning Group] but actually, we don't, as an organisation the make-up is a much greater split for local authorities. So they are doing all they can to protect us. I think the voluntary organisations with smaller grants are dwindling, the smaller amounts of funding for the sector are dwindling, which is in itself a risk and that's something that we fight hard against. But strategically they do view us as important in terms of achieving their public service reform and in fact it has been said by the cabinet portfolio holders around in Oldham and others, that we are their answer to that, that's how they see the change in the relationships between citizens and the wider population and the public services (Interview 3, Oldham Voluntary Organisation, 2016).

The end of this quote from the Oldham interviewee also touches on the important shifts within the positionality of civil society; it acknowledges how the local state is a deeply contradictory 'agent and obstacle' (Duncan \& Goodwin, 1989). Civil society is, firstly, drawn into the local state as a necessity of funding. Secondly, it is somewhat powerless in the context of restructuring and cuts, as civil society groups are further distanced from having a strategic voice. Here, the paradox of austerity in the context of scale suggests that at local level, civil society actors are needed more than ever, stepping into the austerity void (DeVerteuil, 2016; Dear \& Wolch, 1987) and increasingly being relied on to deliver public services. However, at a city region level are being afforded a minor voice. This is especially true within GMRC, due to the devolved nature of health and social care, but this is also noted in Sheffield:

I think it's probably changed enormously actually. I think - well there's a number of pros and cons, I think with the current government policy and the austerity measures everything that's going on in terms of shrinking the states, promoting using third sector organisations and growing civil society has brought some opportunities for the third sector. There's definitely, for example, funding streams that the third sector can access that statutory organisations can't access so having said that, they are highly competitive (Interview 6, Sheffield Youth Development Organisation, 2015).

As illustrated above, within the context of austerity, opportunities have arisen for civil society groups, even despite the highly competitive nature of funding. However, the jumping of scale to the city region and realignment of governance alongside austerity has also been created destabilising experiences. This is discussed below. 


\section{Responding and Repositioning within City Regions}

Within GMRC, this terrain has articulated a response from civil society groups via the Greater Manchester Voluntary, Community and Social Enterprise (VCSE) Devolution Reference Group (VCSE, 2016). The group was formed in response to devolution due to the failure of Greater Manchester Combined Authority (GMCA) to engage such organisations. This represents an attempt by the various actors to find a voice and influence the direction of devolution (and potentially in turn the Northern Powerhouse) by their collective knowledge and access to different parts of GMCA.

According to one account:

The reference group was set up when we realised that all this was going on around us and nobody was going to come banging down our door...So from that a little coalition of the willing emerged, completely undemocratically but again I think that's part of it. Stop waiting for permission, stop feeling like you have to get every detail right. Because actually things are moving so fast, we have to trust each to advocate for what our sector wants to collectively achieve (Interview 4, Manchester Voluntary Organisation, 2016).

Although the group, does not give full democratic representation for civil society at large, it represents an attempt to jump scales (Cox, 1997) by organisations that for the most part do not exist on a city region scale. The above quote also highlights the failure of the GMCA to address the needs of civil society within the context of devolution and the groups desire to be part of the processes, conversations and the representational regime of the city in the context of devolution. One interviewee develops this further:

The pace of change of devolution has been about the public sector thinking about the public sector and their internal mechanism ways of working override that belief that we're important partners. I think we as a group, I'm going to use your term, 'civil society' but voluntary sector and social enterprises. By having that collective group that is able to in some part have representative round tables, to have the ability to talk to some of the key individuals, as a collective to be able to do that, that is important (Interview 3, Oldham Voluntary Organisation, 2016).

In contrast to the LEP and its privileged position for business leaders, who work in conjunction with city region CAs, groups like the VCSE have had to find other ways to reposition themselves within the devolved CA. This represents how the UK Government, with its emphasis upon economic development has sought to shape devolution from the centre. By its very structure, it has defined who is and who is not involved and although each city region will implement its city deal differently, the 'rules of the game' have been initially shaped in one direction in terms of creating a new 'citizenship regime' under devolution (Jenson \& Phillips, 1996; Rutherford, 2006). This raises serious questions around representation and recognition in the pursuit of economic growth and this is something that all respondents from civil society backgrounds have recognized. In identifying this, they have attempted to find ways to try and place their agendas towards inequality and the social reproduction of the city region back into the processes of city region building. These processes are currently unfolding and the success of such positioning will only become clear as the city region is delivered in the coming years. 


\section{Conclusions}

This chapter has addressed the changes being created by the unfolding process of devolving power to two of the Northern Powerhouse's key city regions. Within this, it has attempted to understand how civil society is being positioned. The aim has been to think through the ways in which, if the Northern Powerhouse is to be successful and be more than just a 'spatial imaginary' (Jessop, 2015) in which a 'rag bag' set of policies fall (Lee, 2016), it needs to deal more seriously with issues surrounding inequality and uneven development in each of its constitutive city regions.

As the chapters elsewhere in this book note, the Northern Powerhouse is supposed to be a project that will bring prosperity to the North of England, but evidence suggests that its model of agglomerative economic growth, fostered on trickledown economics, will only continue to exacerbate uneven development and undermine the project of spatial rebalancing. In conducting interviews with civil society actors, this chapter has highlighted how in the context of city region building, the current approach to city regional economic development and governance is falling short of its promises. We have suggested that this is due, in part, to who has been enabled within the Northern Powerhouse city region agenda and who has been marginalized in this process. Further to this, the new citizenship regimes implemented within city regions places civil society outside of decision making processes, whilst expecting civil society to deal with the fallout from continuing uneven development, socio-spatial inequalities and austerity.

The Northern Powerhouse faces an uncertain future since Brexit due to the switch towards an industrial strategy for the UK and the largely repacking of existing committed expenditure with little new to create regional distinctiveness (compare Berry, 2016; HM Treasury, 2016). The pendulum of UK economic development may have turned away from the spatial imaginaries of the Northern Powerhouse and the city region to focus on the national level again, but the spatial dimensions and sub-national dynamics of this remain unclear. Moreover, as we have argued here, there remains a need to re-balance relationships between the economy, state and civil society, so that a more representational form of devolution can be delivered. We would suggest that this requires a much stronger attempt to integrate 'the social' alongside the economic within devolution if a more inclusive growth strategy is to be achieved. 


\section{Bibliography}

Beatty, C. \& Fothergill, S., 2016. The Uneven Impact of Welfare Reform, Sheffield: Sheffield Hallam University.

Berry, C., 2016. Industrial policy change in the post-crisis British economy: Policy innovation in an incomplete institutional and ideational environment. The British Journal of Politics and International Relations, 18(4), pp.829-847.

Clarke, G., Martin, R. \& Tyler, P., 2016. Divergent cities? Unequal urban growth and development. Cambridge Journal of Regions, Economy and Society, 9(2), pp.259-268.

Clarke, N. \& Cochrane, A., 2013. Geographies and politics of localism: The localism of the United Kingdom's coalition government. Political Geography, 34, pp.10-23.

Cox, K.., 1997. Spaces of dependence, spaces of engagement and the politics of scale, ore looking for local politics. Policitcal Geography, 17(I), pp.1-22.

Dear, M.J. \& Wolch, J.R., 1987. Landscapes of despair : from deinstitutionalization to homelessness, Cambridge: Polity Press.

DeVerteuil, G., 2016. Resilience in the post-welfare inner city : voluntary sector geographies in London, Los Angeles and Sydney, Bristol: Polity Press.

Duncan, S. \& Goodwin, M., 1989. The Local State and Uneven Development, London: Polity Press.

Etherington, D. \& Jones, M., 2016a. Devolution and Disadvantage in the Sheffield City Region: An assessment of employment, skills, and welfare policies, Sheffield: University of Sheffield.

Etherington, D. \& Jones, M., 2016b. The city-region chimera: the political economy of metagovernance failure in Britain. Cambridge Journal of Regions, Economy and Society, 9(2), pp.371-389.

Gardiner, B. et al., 2013. Spatially unbalanced growth in the British economy. Journal of Economic Geography, 13(6), pp.889-928.

Goodwin, M., Jones, M. \& Jones, R., 2005. Devolution, constitutional change and economic development: Explaining and understanding the new institutional geographies of the British state. Regional Studies, 39(4), pp.421-436.

Harrison, J., 2014. Rethinking City-regionalism as the Production of New Non-State Spatial Strategies: The Case of Peel Holdings Atlantic Gateway Strategy. Urban Studies, 51(11), pp.2315-2335.

Harrison, J. \& Heley, J., 2014. Governing beyond the metropolis: Placing the rural in city-region development. Urban Studies, 52(6), pp.1113-1133.

Haughton, G., Allmendinger, P. \& Oosterlynck, S., 2013. Spaces of neoliberal experimentation: Soft spaces, postpolitics, and neoliberal governmentality. Environment and Planning A, 45(1), pp.217-234.

HM Government \& North, T. for the, 2015. The Northern Powerhouse: One Agenda, One Economy, One North, Available at:

https://www.gov.uk/government/uploads/system/uploads/attachment_data/file/427339/thenorthern-powerhouse-tagged.pdf (Accessed 15/12/2016).

HM Treasury, 2016. Northern Powerhouse strategy, Available at: 
https://www.gov.uk/government/publications/northern-powerhouse-strategy. (Accessed 15/12/2016).

Jenson, J. \& Phillips, S.D., 1996. Regime Shift: New Citizenship Practices in Canada. International Journal of Canadian Studies, 14, pp.111-136.

Jenson, J. \& Saint-martin, D., 2010. New Routes to Social Cohesion ? Citizenship and the Social Investment State. 28(1), pp.77-99.

Jessop, B., 2015. The State: Past, Present, Future. Cambridge: Polity Press.

Jonas, A.E.G. \& Ward, K., 2007. Introduction to a Debate on City-Regions: New Geographies of Governance, Democracy and Social Reproduction. International Journal of Urban and Regional Research, 31(1), pp.169-178.

Jonas, A.E.G. \& Wilson, D., 1999. The Urban Growth Machine: Critical Perspectives, Two Decades Later, London: SUNY Press.

Jones, G., Meegan, R., Kennet, P. \& Croft, J. 2015. The uneven impact of austerity on the voluntary and community sector: A tale of two cities. Urban Studies, 53(10), pp.2064-2080.

Lee, N., 2016. Powerhouse of Cards? Understanding the "Northern Powerhouse." Regional Studies. Online First see http://dx.doi.org/10.1080/00343404.2016.1196289.

Logan, J.R. \& Molotch, H.L., 1987. Urban Fortunes: The Political Economy of Place, Berkeley: University of California Press.

MacLeod, G., 2001. New regionalism reconsidered : globalization and the remaking of political economic space. International Journal of Urban and Regional Research. 25(4), pp.804-829.

Macleod, G. \& Goodwin, M., 1999. Reconstructing an urban and regional political economy: on the state, politics, scale, and explanation. Political Geography, 18, pp.697-730.

Martin, R., Sunley, P., Tyler, P., \& Gardiner, B., 2016. Divergent cities in post-industrial Britain. Cambridge Journal of Regions, Economy and Society. 9, pp.269-299.

Overman, H.G., 2012. Investing in the UK's most successful cities is the surest recipe for national growth. , pp.1-2. Available at: http://blogs.Ise.ac.uk/politicsandpolicy/ (Accessed 15/12/2016).

Peck, J. \& Theodore, N., 2015. Fast policy : experimental statecraft at the thresholds of neoliberalism. Minnneapolis: University of Minnesota.

Pike, A., Rodriguez-Pose, J., Tomaney, J., Torrisi, G., \& Tselios, V., 2012. In search of the "economic dividend" of devolution: spatial disparities, spatial economic policy, and decentralisation in the UK. Environment and Planning C: Government and Policy, 30(1), pp.10-28.

Pugalis, L. \& Townsend, A.R., 2012. Rebalancing England: sub-national development (once again) at the crossroads. Urban Research \& Practice, 5(1), pp.157-174.

RSA, 2016a. Inclusive Growth Commission Emerging Findings Foreword (September). Available at https://www.thersa.org/discover/publications-and-articles/reports/emerging-findings-of-theinclusive-growth-commission. (Accessed 15/12/2016).

RSA, 2016b. Inclusive growth for people and places (September) Available at https://www.thersa.org/discover/publications-and-articles/reports/inclusive-growth-forpeople-and-places-challenges-and-opportunities (Accessed 15/12/2016). 
Rutherford, T.D., 2006. Local representations in crisis: Governance, citizenship regimes, and UK TECS and Ontario local boards. Environment and Planning D: Society and Space, 24(3), pp.409-426.

Scott, A.J., 2001. Globalization and the Rise of City-regions. European Planning Studies, 9(7), pp.813826.

Storper, M., 2013. Keys to the City: How Economics, Institutions, Social Interaction, and Politics Shape Development. Princeton: Princeton Univerity Press.

VCSE, 2016. Greater Manchester Voluntary, Community and Social Enetprise (VCSE) Devolution Reference Group. Available at https://www.gmcvo.org.uk/system/files/gm_vcse_devolution_reference_group__information_sheet.pdf (Accesssed 15/12/2016). 